\title{
HUBUNGAN MINAT MEMBACA BUKU KIA DENGAN PENGETAHUAN IBU HAMIL TENTANG BUKU KIA
}

\author{
THE RELATIONSHIP BETWEEN READING INTEREST OF KIA BOOK WITH \\ PREGNANT MOTHERS KNOWLEDGE ABOUT KIA BOOK
}

\author{
Faradina Nur Annisa \\ Departemen Promosi Kesehatan dan Ilmu Perilaku, \\ Fakultas Kesehatan Masyarakat, Universitas Airlangga, Surabaya. \\ Email: annisafaradina9@gmail.com
}

\begin{abstract}
Maternal Mortality Rate (MMR) in Indonesia is still high relatively, recent data from the World Health Organization in 2011 the MMR in Indonesia is 240/100 thousands birth rate. One of the effort developed by Ministry of Health is empowering families and people by KIA book. KIA book is an important book for pregnant mothers. One of way to get knowledge well, a person must have an interest to read. This research aimed for knowing the relationship between reading interest of KIA book with pregnant mothers knowledge about KIA book. Research This research used analytic observational with cross sectional approach. Population in this research is all of pregnant mothers in the $2^{\text {nd }}$ and $3^{\text {rd }}$ semester that have KIA book in Rural Clinic Pulungdowo Tumpang, with the amount of population is 36 people. Sample taking use purposive sampling technique with the number of 33 people. Data processing displayed in the frequency distribution table and analyzed using Spearman Rank correlation test, research result shows that half of respondent, 33.3\% has high interest and well knowledge. Based Spearman Rank test with significance level 0.05, obtained significance value $0.000<0.05$, it means that there is a relationship between reading interest of KIA book with pregnant mothers knowledge about KIA book.
\end{abstract}

Keywords: Reading interest, Pregnant mothers, KIA book, Knowledge

\begin{abstract}
Abstrak: Angka Kematian Ibu (AKI) di Indonesia masih relatif tinggi, data terakhir dari WHO pada tahun 2011 AKI di Indonesia sebesar 240/100 ribu KH. Salah satu upaya yang dikembangkan oleh Depkes $\mathrm{RI}$ adalah dengan mengupayakan pemberdayaan keluarga dan masyarakat melalui penggunaan buku Kesehatan Ibu dan Anak (KIA). Buku KIA adalah buku yang penting untuk ibu hamil. Pengetahuan yang baik bisa diperoleh dengan salah satunya seseorang harus memiliki minat untuk membaca. Penelitian ini bertujuan untuk mengetahui hubungan antara minat membaca buku KIA dengan pengetahuan ibu hamil tentang buku KIA. Penelitian ini adalah observasional analitik dengan pendekatan kuantitatif. Rancang bangun yang digunakan adalah cross sectional. Populasinya adalah semua ibu hamil trimester II dan III yang memiliki buku KIA di Polindes Pulungdowo Tumpang. Pengambilan sampel menggunakan teknik purposive sampling dengan jumlah 33 orang. Pengolahan data disajikan dalam tabel distribusi frekuensi dan dianalisa menggunakan uji korelasi Spearman Rank. Hasil penelitian menunjukkan bahwa hampir setengah dari responden 33,3\% memiliki minat membaca tinggi dan pengetahuan baik. Dari hasil uji Spearman Rank dengan tingkat signifikasi 0,05 diperoleh $p$ value $0,000<0,05$ sehingga dapat disimpulkan bahwa ada hubungan antara minat membaca buku KIA dengan pengetahuan ibu hamil tentang buku KIA.
\end{abstract}

Kata kunci: Minat membaca, Ibu hamil, Buku KIA, Pengetahuan

\section{PENDAHULUAN}

Indonesia memiliki Angka Kematian Ibu yang relatif tinggi apabila dibandingkan dengan beberapa anggota negara ASEAN. Angka Kematian Ibu (AKI) adalah salah satu indikator dalam menentukan derajat kesehatan perempuan. Angka Kematian Ibu menurut Survey Demografi Kesehatan Indonesia (SDKI) pada tahun 2005 adalah
202/100.000 kelahiran hidup, tahun 2007 adalah 228/100.000 kelahiran hidup. Data terakhir menurut Survey Demografi Kesehatan Indonesia (SDKI) tahun 2012, Angka Kematian Ibu di Indonesia masih cukup tinggi yaitu 359/100.000 kelahiran hidup.

Derajat kesehatan masyarakat serta keberhasilan dalam pembangunan di 
sektor kesehatan adalah indikator yang dapat ditentukan oleh Angka Kematian Ibu (Kemenkes RI, 2010). Usaha-usaha dilakukan untuk menanggulangi masalah Angka Kematian Ibu seperti adanya program Making Pregnancy Safer (MPS) atau dikenal dengan program menciptakan kehamilan yang lebih aman yang dilaksanakan oleh World Health Organization (WHO) serta program Safe Motherhood yang biasa dikenal dengan program gerakan sayang ibu yang dilakukan oleh pemerintah Indonesia.

Depkes RI (2009), melakukan upaya untuk mengurangi angka kesakitan, risiko tinggi, kematian maternal dan neonatal yaitu dengan penggunaan Buku KIA yang bertujuan untuk pemberdayaan antara keluarga dan masyarakat. Buku Kesehatan Ibu dan Anak (KIA) adalah buku yang berisi tentang informasi kesehatan ibu dan anak yang bisa digunakan untuk melakukan pencatatan dan penyuluhan tentang kesehatan ibu dan anak. Buku KIA bisa digunakan oleh ibu dan keluarga. Informasi-informasi kesehatan yang ada pada buku KIA bisa membantu keluarga dalam meningkatkan kesehatan ibu dan anak.

Tujuan dari Buku KIA adalah memperbaiki perilaku keluarga dan masyarakat dalam memelihara kesehatan ibu dan anak dan meningkatkan komunikasi antara provider dan klien untuk membantu keluarga memperoleh pelayanan KIA yang bermutu dan berkesinambungan (Azrul, 2003). Sasaran dari pengguna buku KIA terdiri dari dua bagian, yaitu sasaran langsung seperti ibu dan anak, dan sasaran tidak langsung seperti suami dan anggota keluarga yang lain, kader posyandu, petugas kesehatan, guru Taman Kanak-kanak (TK), supervisor dan pengelola program yang bertanggung jawab dalam pengembangan buku KIA.

Menurut Depkes RI (2009), buku KIA terdiri dari dua bagian isi, yaitu bagian anak dan bagian ibu. Bagian kesehatan anak mencakup tentang identitas anak, bayi baru lahir dan anak, balita, catatan pelayanan kesehatan anak, dan catatan penyakit dan masalah perkembangan. Bagian untuk kesehatan ibu berisi identitas keluarga, ibu hamil, ibu bersalin, ibu nifas, Keluarga Berencana (KB), dan catatan pelayanan kesehatan ibu. Isi untuk kesehatan ibu hamil diantaranya adalah periksa kehamilan secara rutin, persiapan melahirkan (bersalin), perawatan sehari-hari, anjuran makan buat ibu hamil, tanda bahaya pada kehamilan, dan masalah lain pada kehamilan.

Buku KIA merupakan sarana komunikasi antara ibu hamil dan petugas kesehatan, dimana petugas kesehatan bisa melihat catatan-catatan penting yang diberikan petugas kesehatan lain. Buku KIA mencakup semua informasi penting tentang kondisi kesehatan pada ibu serta pada anak. Buku KIA disarankan untuk dimiliki oleh para ibu yang sedang hamil sehingga dapat mengurangi risiko gangguan kesehatan ibu hamil.

Buku KIA yang diberikan kepada ibu hamil terdapat Stiker Perencanaan Persalinan dan Pencegahan Komplikasi (P4K) pada bagian depan (cover) atau belakang buku yang berisi tindakan-tindakan antisipasi yang perlu dilakukan pada saat sebelum proses persalinan. Stiker ini nantinya akan dipasang oleh Petugas Kesehatan di tempat yang mudah dilihat seperti di bagian depan rumah ibu hamil. Setiap ibu hamil wajib memiliki buku KIA dan membaca buku KIA agar para ibu hamil mengetahui keadaan kesehatannya serta apabila terjadi suatu kelainan atau komplikasi bisa mendeteksi secara lebih dini.

Pada tanggal 18 Februari 2013 dilakukan studi pendahuluan yang berlokasi di Polindes Pulungdowo Tumpang didapatkan hasil bahwa jumlah seluruh ibu hamil pada bulan Februari 2013 ada 41 orang. Proses wawancara sederhana dilakukan pada 5 ibu hamil dan mendapatkan hasil bahwa ibu hamil tidak membaca isi dari buku KIA, mereka berpendapat buku KIA hanya sebagai pelengkap persyaratan saat melakukan pemeriksaan kehamilan.

Hampir sama dengan penelitian yang dilakukan oleh Sistiarani (2012) yang berjudul "Fungsi Pemanfaat Buku KIA terhadap Pengetahuan Kesehatan Ibu dan Anak pada Ibu" di Puskesmas Ajibarang I Jawa Tengah. Hasil penelitian menjelaskan bahwa pemanfaatan buku KIA masih belum maksimal terbukti dari data cakupan buku KIA Puskesmas Ajibarang I sekitar $72,34 \%$ yang masih di bawah target 
Standar Pelayanan Minimal. Oleh sebab itu penelitian ini tertarik untuk mengambil topik tentang minat membaca buku KIA pada ibu hamil.

Menurut Rahim (2008), minat membaca adalah kesadaran dan keinginan kuat yang dimiliki oleh seseorang dengan menyediakan bahan bacaan serta berusaha untuk membacanya. Unsur-unsur yang terkandung di dalam minat adalah, unsur mengenal (kognisi) mempunyai artian minat mengetahui suatu objek yang muncul melalui informasi dan pengetahuan yang diketahui sebelumnya. Unsur emosi (perasaan) yaitu respons terhadap objek ataupun aktivitas tertentu (biasanya didasari rasa senang). Unsur kehendak (konasi) adalah perpaduan dari dua unsur sebelumnya yaitu hasrat dan kemauan yang timbul untuk melakukan suatu kegiatan yang disertai dengan rasa senang.

Beberapa faktor yang memengaruhi minat seseorang dalam membaca adalah berasal dari dalam dan luar. Faktor berasal dari dalam seperti kebiasaan, tingkat pendidikan, pembawaan/bakat, keadaan kesehatan, jenis kelamin, dan keadaan jiwa. Sedangkan faktor berasal dari luar seperti lingkungan, kebutuhan, dan buku/bahan bacaan (Soeatminah, 1992). Seorang ibu hamil yang merasa tertarik dengan buku KIA maka akan perhatian dan termotivasi untuk minat membaca buku KIA. Ibu hamil mempunyai minat membaca buku KIA akan meluangkan waktu untuk membaca sehingga pengetahuan ibu tentang buku KIA akan menjadi meningkat (Soeatminah, 1992).

Notoatmodjo (1992) menjelaskan bahwa pengetahuan ialah hasil dari pengindraan yang dilakukan oleh seseorang terhadap suatu objek tertentu sehingga orang tersebut menjadi tahu. Pengalaman yang didapat oleh seseorang dari berbagai macam sumber seperti dari buku, media poster, media elektronik dan media massa serta petugas kesehatan dapat mempengaruhi pengetahuan orang tersebut. Pengetahuan yang dimiliki seseorang nantinya akan membentuk keyakinan yang nantinya mempengaruhi orang tersebut dalam berperilaku (Istiarti, 2000).

Pengetahuan mempunyai enam tingkatan yang terdiri dari tahu (know) yaitu mengerti dan mengingat mengenai materi yang telah dipelajari; memahami (comprehension) yaitu kemampuan menginterpretasikan suatu materi dengan benar dan dapat mengutarakan objek yang telah dipelajari secara jelas; aplikasi (application) yaitu kemampuan dalam menerapkan materi yang telah dipelajari pada kondisi atau situasi sebenarnya (real); analisis (analysis) adalah kemampuan menjabarkan materi atau objek ke dalam komponen dalam suatu struktur organisasi namun masih terdapat kaitan antara satu dengan yang lainnya; sintesis (synthesis) menggambarkan kemampuan dalam menghubungkan atau meletakkan bagianbagian ke dalam bentuk keseluruhan yang baru; evaluasi (evaluation) mempunyai artian kemampuan seseorang melakukan sebuah penelitian terhadap suatu objek atau materi.

Cara Mendapatkan pengetahuan diklasifikasikan menjadi dua macam, yaitu (1) Cara Tradisional seperti Cara Coba Salah (Trial and Error) yakni mencoba beberapa kemungkinan yang ada sampai berhasil, periode ini terjadi karena belum ditemukannya metode ilmiah. Cara kekuasaan atau otoritas adalah mendapatkan pengetahuan berdasarkan otoritas atau kekuasaan baik melalui otoritas pemimpin agama, otoritas pemerintahan, ahli ilmu pengetahuan maupun tradisi yang ada; manusia dianggap telah mampu menggunakan penalarannya dalam memperoleh pengetahuan ketika cara yang digunakan pada masa lalu dalam menghadapi permasalahan pribadi dan berhasil dipecahkan dijadikannya pedoman dalam menghadapi permasalahan yang akan dihadapi di masa yang akan datang; (2) Memperoleh pengetahuan dengan cara modern pada saat ini bisa didapatkan dengan cara melakukan metode penelitian ilmiah, dimana pengetahuan ini lebih bersifat logis, sistematis dan ilmiah (Notoatmodjo, 2010).

Pengetahuan dipengaruhi oleh beberapa faktor antara lain intelegensi ialah kemampuan seseorang untuk bertindak secara efektif dan rasional; usia yaitu dengan semakin bertambahnya usia seseorang maka pengalaman yang dimiliki juga akan semakin bertambah; pendidikan merupakan salah 
satu faktor yang menentukan penyerapan informasi; pengalaman dimana perasaan dan pemikiran seseorang dalam berperilaku yang terbentuk dalam sikap, pengetahuan, persepsi, kepercayaan dan penilaian terhadap suatu objek tertentu; informasi yaitu suatu sistem yang mempunyai pengaruh sangat besar terhadap perubahan pemeliharaan; dan lingkungan sebagai sumber untuk belajar.

Tujuan penelitian ini adalah mengetahui hubungan antara minat membaca buku KIA dengan pengetahuan ibu hamil tentang buku KIA. Penelitian ini bertujuan mengidentifikasi minat membaca buku KIA pada ibu hamil, mengidentifikasi pengetahuan ibu hamil tentang buku KIA, dan menganalisis hubungan antara minat membaca buku KIA dengan pengetahuan ibu hamil tentang buku KIA.

\section{METODE}

Penelitian ini adalah observasional analitik dengan pendekatan kuantitatif. Rancang bangun yang digunakan adalah cross sectional. Penelitian ini dilakukan di Polindes Pulungdowo Tumpang Kabupaten Malang. Penyusunan karya tulis ilmiah ini sampai dengan penelitian dilaksanakan pada bulan Maret sampai bulan Juli 2013 mulai dari penyusunan proposal, pengumpulan data, pengolahan data, analisis data serta penulisan hasil penelitian.

Populasi pada penelitian ini adalah total ke seluruh ibu hamil trimester II dan III yang tercatat di Polindes Pulungdowo Tumpang dan memiliki buku KIA pada tanggal 01 April-06 April 2013 sebanyak 36 ibu hamil. Sampel dalam penelitian ini adalah sebagian dari populasi yang memenuhi kriteria inklusi yang terdiri dari tercatat pada polindes Pulungdowo Tumpang Malang dan bersedia menjadi responden. Sampel dihitung dengan rumus perhitungan sampel sebagai berikut:

$$
\begin{aligned}
n & =\frac{N}{1+N\left(d^{2)}\right.} \\
n & =\frac{36}{1+36(0,05)^{2}} \\
& =\frac{36}{1+0.09} \\
& =\frac{36}{1.09} \\
& =33,027
\end{aligned}
$$

Jadi total sampel yang didapatkan adalah 33 orang ibu hamil. Teknik dalam pengambilan sampel menggunakan purposive sampling yaitu cara memilih sampel berdasarkan alasan dan pertimbangan yang telah ditentukan artinya ibu hamil trimester II dan III yang tercatat di Polindes Pulungdowo Tumpang.

Variabel dalam penelitian ini terdiri dari dua jenis, yaitu variabel independen yang terdiri dari minat membaca yang mengandung 3 hal yakni ketertarikan, perhatian, dan motivasi, serta variabel dependen adalah pengetahuan tentang buku KIA yang terdiri dari pengertian buku KIA, manfaat buku KIA, sasaran buku KIA dan isi buku KIA yang mencakup kesehatan ibu hamil.

Instrumen penelitian yang digunakan dalam pengumpulan data adalah kuesioner minat membaca buku KIA dan pengetahuan tentang buku KIA yang dilakukan pada saat yang bersamaan. Kuesioner minat membaca terdiri dari dua jenis pernyataan, yaitu pernyataan favourable yang bersifat positif dan pernyataan unfavourable yang bersifat negatif. Kuesioner tentang pengetahuan berisi pertanyaan tentang pengertian buku KIA, manfaat buku KIA, sasaran buku KIA dan isi buku KIA yang mencakup kesehatan ibu hamil. Kuesioner dibuat sendiri oleh peneliti yang sebelumnya sudah dilakukan uji validitas untuk menguji kevalidan dan juga reliabilitas untuk menguji reliable dari kuesioner.

Uji validitas dalam penelitian ini menggunakan bantuan komputer dengan progam SPSS. R tabel didapatkan sebesar 0.632 , jika $r$ hitung $\geq 0.632$ maka pernyataan dinyatakan valid dan jika $r$ hitung $\leq 0.632$ maka pernyataan dinyatakan tidak valid. Hasil yang diperoleh dari 25 butir soal kuesioner minat, jumlah soal yang valid ada 22 soal dan tidak valid ada 3 soal yang kemudian tidak digunakan dan didapatkan $\mathrm{r}$ hitung dengan rentang antara $0,674-0,955$. Dari 25 butir soal kuesioner pengetahuan, jumlah soal yang valid ada 21 dan yang tidak valid ada 4 soal yang kemudian tidak digunakan juga dan didapatkan $\mathrm{r}$ hitung dengan rentang antara $0,703-0,890$.

Uji reliabilitas instrumen menggunakan Cronbach Alpha yang diketahui nilai 
Cronbach Alpha untuk kuesioner minat sebesar 0,974 dan untuk kuesioner pengetahuan sebesar 0,965 . Nilai kritis yang digunakan sebesar 0,6 sebagai pembanding, karena nilai Cronbach Alpha lebih besar dari nilai kritis pembanding, sehingga didapatkan hasil bahwa variabel pertanyaan tersebut adalah reliabel dan dapat digunakan pada penelitian. Kuesioner yang telah valid dan reliabel berjumlah 43 soal, yang terdiri dari 22 soal tentang minat membaca buku KIA dan 21 soal tentang pengetahuan ibu hamil tentang buku KIA.

Minat membaca responden pada penelitian ini dikategorikan menjadi tiga kategori, yaitu tinggi, sedang dan rendah. Perhitungan nilai minat membaca menggunakan skala likert yang terbagi atas pernyataan positif dan pernyataan negatif.

\section{Pernyataan positif}

Sangat setuju (SS)

Setuju (S)

Tidak Setuju (TS)

Sangat Tidak Setuju (STS) $\quad: 1$

\section{Pernyataan negatif}

Sangat setuju (SS) $\quad: 1$

Setuju (S) $\quad: 2$

Tidak Setuju (TS) : 3

Sangat Tidak Setuju (STS) $\quad: 4$

Hasil penjumlahan minat membaca yang telah dilakukan, akan dimasukkan ke dalam rumus skor $\mathrm{T}$ yang terbagi ke dalam tiga kategori minat membaca, yaitu tinggi, sedang dan rendah. Rumus skor $\mathrm{T}$ adalah sebagai berikut:

$$
\text { Tskor }=50+10 \frac{[x-\bar{x}]}{S d}
$$

Penggolongan subjek ke dalam tiga kategori minat membaca yaitu sebagai berikut:

Tinggi $: 60 \leq X$

Sedang : $40 \leq X<60$

Rendah : $\mathrm{X}<40$

(Azwar, 2007)

Kriteria pengetahuan yang digunakan dalam penelitian ini terdiri dari tiga kategori, yaitu baik, cukup dan kurang. Skor dalam perhitungan pengetahuan adalah nilai 1 untuk jawaban yang benar dan nilai 0 untuk jawaban yang salah. Rumus yang digunakan untuk mengukur pengetahuan tentang buku KIA adalah sebagai berikut:

$$
\mathrm{P}=\frac{f}{N} \times 100 \%
$$

Hasil perhitungan rumus yang sudah didapatkan dimasukkan dalam kriteria standar penilaian pengetahuan sebagai berikut :

Baik : hasil persentase $76 \%-100 \%$

Cukup : hasil persentase 56\%-75\%

Kurang : hasil persentase $<56 \%$

(Nursalam,2008)

Penyajian data kualitatif dijadikan data kuantitatif menggunakan kriteria sebagai berikut:

$$
\begin{array}{ll}
100 \% & : \text { seluruhnya } \\
76 \%-99 \% & : \text { hampir seluruhnya } \\
51 \%-75 \% & : \text { sebagian besar } \\
50 \% & : \text { setengahnya } \\
26 \%-49 \% & : \text { hampir setengah } \\
1 \%-25 \% & : \text { sebagian kecil } \\
0 \% & \text { : tidak satupun }
\end{array}
$$

(Setiadi, 2007)

Hasil pengukuran tentang minat membaca buku KIA dan pengetahuan tentang buku KIA yang telah diketahui, kemudian dilakukan analisis hubungan antar variabel, yaitu variabel independen (minat membaca) berskala data ordinal dan variabel dependen (pengetahuan) berskala data ordinal. Analisis data dilakukan dengan menggunakan uji koefisien korelasi Spearman Rank terhadap dua variabel yang diduga berhubungan menggunakan taraf signifikan 0,05 (5\%).

\section{HASIL PENELITIAN}

Tabel 1. menunjukkan bahwa distribusi umur responden hampir seluruhnya termasuk dalam fase dewasa awal yaitu berumur 20-40 tahun. Fase ini merupakan fase dengan umur yang produktif dan aktif dalam menjalani kehidupan sehari-hari. 
Tabel 1. Distribusi Frekuensi Berdasarkan Umur, Pendidikan, Pekerjaan, dan Jumlah Kehamilan Responden di Polindes Pulungdowo-Tumpang Bulan April 2013

\begin{tabular}{lrc}
\hline \multicolumn{1}{c}{ Distribusi } & $\begin{array}{c}\text { Frekuensi } \\
\text { (F) }\end{array}$ & $\begin{array}{c}\text { Persentase } \\
(\%)\end{array}$ \\
\hline Umur & & \\
16-19 tahun & 3 & 9,1 \\
20-40 tahun & 30 & 90,9 \\
\hline Pendidikan & & \\
SD & 3 & 9,1 \\
SMP & 8 & 24,3 \\
SMA & 18 & 54,5 \\
Perguruan Tinggi & 4 & 12,1 \\
\hline Pekerjaan & & \\
Buruh/Petani & 2 & 6,1 \\
Swasta & 5 & 15,1 \\
PNS & 3 & 9,1 \\
Ibu RumahTangga & 23 & 69,7 \\
\hline Jumlah Kehamilan & & \\
1 (satu) & 12 & 36,4 \\
2 (dua) & 13 & 39,4 \\
3 (tiga) & 8 & 24,2 \\
\hline
\end{tabular}

Sebagian besar responden berpendidikan SMA dan sudah menamatkan pendidikan $\mathrm{SD}$, hal ini berarti bahwa responden sudah bisa membaca suatu bahan bacaan yaitu buku KIA dalam penelitian ini. Sebagian besar responden bekerja sebagai ibu rumah tangga dan lebih banyak menghabiskan waktu di rumah. Hampir dari setengah jumlah responden sudah pernah mempunyai pengalaman hamil sehingga mereka sudah tidak asing lagi dengan buku KIA yang wajib dibawa saat ibu hamil melakukan pemeriksaan kehamilan di fasilitas kesehatan.

Tabel 2. menunjukkan bahwa hampir setengah dari responden yaitu 11 orang $(33,3 \%)$ memiliki minat tinggi dan 16 orang (48,5\%) memiliki minat membaca sedang, dan sebagian kecil responden yaitu 6 orang $(18,2 \%)$ memiliki minat membaca rendah. Sebagian besar responden yaitu sebanyak 19 orang $(57,6 \%)$ memiliki pengetahuan baik, sedangkan hampir setengah responden yaitu 10 orang $(30,3 \%)$ memiliki pengetahuan cukup dan sebagian responden yaitu 4 orang $(12,1 \%)$ memiliki pengetahuan kurang. Sebagian besar responden bisa menjawab pertanyaan tentang pengertian buku KIA,
Tabel 2. Distribusi Frekuensi Minat Membaca dan Pengetahuan Tentang Buku KIA pada Responden di Polindes Pulungdowo Tumpang Bulan April 2013

\begin{tabular}{lcc}
\hline Distribusi & $\begin{array}{c}\text { Frekuensi } \\
(\mathbf{F})\end{array}$ & $\begin{array}{c}\text { Persentase } \\
\mathbf{( \% )}\end{array}$ \\
\hline Minat Membaca & & \\
$\quad$ Tinggi & 11 & 33,3 \\
Sedang & 16 & 48,5 \\
Rendah & 6 & 18,2 \\
\hline Pengetahuan & & \\
Baik & 19 & 57,6 \\
Cukup & 10 & 30,3 \\
Kurang & 4 & 12,1 \\
\hline
\end{tabular}

manfaat buku KIA, sasaran buku KIA, dan isi buku KIA yang mencakup kesehatan ibu hamil dengan benar.

Tabel 3. menunjukkan bahwa dari 18 responden yang berpendidikan SMA, setengahnya memiliki minat membaca dengan kategori tinggi berjumlah 9 orang $(50 \%)$. Seluruh responden yang berpendidikan SD yaitu 3 responden memiliki minat membaca buku KIA yang rendah (100\%). Ibu hamil yang mempunyai pendidikan terakhir SD merasa kurang tertarik dengan buku KIA dan hanya menggunakan buku KIA saat memeriksakan kehamilannya di fasilitas kesehatan tanpa wajib untuk dibaca sebagai bahan bacaan yang penting untuk ibu hamil selama menjalankan proses kehamilannya. Tabel 4. menunjukkan bahwa responden yang memiliki pengetahuan dengan kategori baik hampir seluruhnya berpendidikan SMA $(77,8 \%)$ dan semua responden yang mempunyai pendidikan terakhir SD memiliki pengetahuan yang rendah.

Tabel 5. menunjukkan bahwa 11 responden yang mempunyai minat membaca tinggi $100 \%$ memiliki pengetahuan baik tentang buku KIA. 16 responden yang mempunyai minat membaca sedang 50\% memiliki pengetahuan baik dan 50\% memiliki pengetahuan cukup tentang buku KIA, sedangkan dari 6 responden yang mempunyai minat membaca rendah $33,3 \%$ memiliki pengetahuan cukup dan $66,7 \%$ memiliki pengetahuan kurang tentang buku KIA. 
Tabel 3. Tabel Silang antara Hubungan Pendidikan dengan Minat Membaca Buku KIA pada Responden di Polindes Pulungdowo Tumpang Bulan April 2013

\begin{tabular}{|c|c|c|c|c|c|c|c|c|}
\hline \multirow{3}{*}{ Pendidikkan } & \multicolumn{6}{|c|}{ Minat Membaca } & \multirow{2}{*}{\multicolumn{2}{|c|}{ Total }} \\
\hline & \multicolumn{2}{|c|}{ Tinggi } & \multicolumn{2}{|c|}{ Sedang } & \multicolumn{2}{|c|}{ Rendah } & & \\
\hline & $\mathbf{F}$ & $\%$ & $\mathbf{F}$ & $\%$ & $\mathbf{F}$ & $\%$ & $\mathbf{F}$ & $\%$ \\
\hline PTN & 1 & 25 & 3 & 75 & 0 & 0 & 4 & 100 \\
\hline SMA & 9 & 50 & 8 & 44,4 & 1 & 5,6 & 18 & 100 \\
\hline SMP & 1 & 12,5 & 5 & 62,5 & 2 & 25 & 8 & 100 \\
\hline SD & 0 & 0 & 0 & 0 & 3 & 100 & 3 & 100 \\
\hline
\end{tabular}

Tabel 4. Tabel Silang antara Hubungan Pendidikan dengan Pengetahuan Responden tentang Buku KIA Di Polindes Pulungdowo Tumpang Bulan April 2013

\begin{tabular}{|c|c|c|c|c|c|c|c|c|}
\hline \multirow{3}{*}{ Pendidikan } & \multicolumn{6}{|c|}{ Pengetahuan } & \multirow{2}{*}{\multicolumn{2}{|c|}{ Total }} \\
\hline & \multicolumn{2}{|c|}{ Baik } & \multicolumn{2}{|c|}{ Cukup } & \multicolumn{2}{|c|}{ Kurang } & & \\
\hline & $\mathbf{F}$ & $\%$ & $\mathbf{F}$ & $\%$ & $\mathbf{F}$ & $\%$ & $\mathbf{F}$ & $\%$ \\
\hline PTN & 4 & 100 & 0 & 0 & 0 & 0 & 4 & 100 \\
\hline SMA & 14 & 77,8 & 4 & 22,2 & 0 & 0 & 18 & 100 \\
\hline SMP & 1 & 12,5 & 6 & 75 & 1 & 12,5 & 8 & 100 \\
\hline SD & 0 & 0 & 0 & 0 & 3 & 100 & 3 & 100 \\
\hline
\end{tabular}

Tabel 5. Tabel Silang antara Hubungan Minat Membaca Buku KIA dengan Pengetahuan Ibu Hamil tentang Buku KIA di Polindes Pulungdowo Tumpang Bulan April 2013

\begin{tabular}{|c|c|c|c|c|c|c|c|c|}
\hline \multirow{3}{*}{ Minat Membaca } & \multicolumn{6}{|c|}{ Pengetahuan } & \multirow{2}{*}{\multicolumn{2}{|c|}{ Total }} \\
\hline & \multicolumn{2}{|c|}{ Baik } & \multicolumn{2}{|c|}{ Cukup } & \multicolumn{2}{|c|}{ Kurang } & & \\
\hline & $\mathbf{F}$ & $\%$ & $\mathbf{F}$ & $\%$ & $\mathbf{F}$ & $\%$ & $\mathbf{F}$ & $\%$ \\
\hline Tinggi & 11 & 100 & 0 & 0 & 0 & 0 & 11 & 100 \\
\hline Sedang & 8 & 50 & 8 & 50 & 0 & 0 & 16 & 100 \\
\hline Rendah & 0 & 12,5 & 2 & 33,3 & 4 & 66,7 & 6 & 100 \\
\hline
\end{tabular}

Analisa untuk mengetahui hubungan antara minat membaca buku KIA dengan pengetahuan ibu hamil tentang buku KIA di Polindes Pulungdowo-Tumpang Kabupaten Malang menggunakan uji korelasi Spearman Rank dengan bantuan perhitungan komputerisasi. Tingkat signifikasi yang digunakan adalah 0,05 dan didapatkan hasil p value sebesar 0,000 , yang artinya $0,000<$ $\alpha(0,05)$. Hasil analisis data menunjukkan bahwa Ho ditolak artinya ada hubungan antara minat membaca buku KIA dengan pengetahuan ibu hamil tentang buku KIA di Polindes Pulungdowo-Tumpang Kabupaten Malang Bulan April 2013.

\section{PEMBAHASAN}

Hasil penelitian menunjukkan, hampir setengah dari responden memiliki minat membaca buku KIA yang cukup. Setengahnya lagi memiliki minat membaca buku KIA yang masih rendah. Farida Rahim (2008) menjelaskan bahwa minat membaca adalah usaha seseorang untuk membaca yang didasari dengan keinginan yang kuat. Minat bisa menjadi salah satu faktor yang mampu menjadi mendorong atau motivasi seseorang untuk membaca. Minat membaca bisa digunakan suatu alat untuk memotivasi seseorang dalam membaca.

Tanda seseorang mempunyai minat membaca adalah adanya kesediaan memperoleh bahan bacaan yang kemudian dibaca atas kesadaran sendiri. Menurut Sukardi (1994), minat muncul karena keinginan dan kemauan dari dalam diri seseorang yang menimbulkan perhatian besar terhadap suatu objek, sehingga membuat seseorang berbuat terhadap 
objek tersebut. Kegiatan membaca akan terwujud apabila seseorang memiliki niat untuk membaca. Terwujudnya kegiatan membaca membutuhkan minat yang mampu memberikan dorongan yang sangat kuat.

Pembentukan minat membaca seseorang membutuhkan proses yang panjang, sama halnya dengan membentuk minat baca ibu hamil terhadap buku KIA. Sebelum mencapai pada minat membaca, responden melewati beberapa proses yaitu ibu hamil mengetahui buku KIA, merasa tertarik dengan materi yang ada di dalam buku KIA. Ibu hamil yang merasa tertarik akan berusaha untuk membaca buku KIA atas kesadarannya sendiri.

Menurut Sumadi (1998), terdapat dua faktor yang mempengaruhi minat membaca yaitu faktor intern dan faktor ekstern. Faktor intern terdiri dari faktor fisiologis dan faktor psikologis, sedangkan faktor ekstern dikategorikan menjadi dua yakni faktor sosial dan faktor non sosial. Konten yang ada di dalam buku KIA merupakan faktor non sosial. Tampilan dan isi dari buku KIA menjadi faktor yang mempengaruhi minat baca ibu hamil. Buku KIA yang dikemas menarik dengan materi yang jelas dan komunikatif akan mampu mendorong minat baca ibu hamil.

Hampir setengah dari responden masih memiliki minat baca yang rendah, hal ini diakibatkan karena masih kurang menariknya tampilan dan materi yang ada di dalam buku KIA. Ibu hamil merasa kurang tertarik sehingga tidak ada keinginan untuk membaca buku KIA dan mengakibatkan masih ada beberapa ibu hamil yang minat membaca buku KIA nya rendah. Selain itu keluarga adalah faktor sosial yang mempengaruhi minat baca. Dukungan dari keluarga akan menjadi motivasi dan mampu membangkitkan minat baca buku KIA pada ibu hamil, dimana motivasi adalah salah faktor yang mampu mendorong minat. Kurangnya media promosi kesehatan seperti poster yang tersedia di fasilitas kesehatan juga membuat ibu hamil juga mempengaruhi ketertarikan ibu hamil terhadap buku KIA.

Tabel silang antara pendidikan dengan minat membaca buku KIA pada ibu hamil menunjukkan bahwa ibu hamil dengan pendidikan terakhir SMA mempunyai minat membaca dengan kategori yang tinggi dan seluruh ibu hamil yang berpendidikan terakhir SD memiliki minat membaca buku KIA yang rendah.

Beberapa hal yang menunjukkan seorang ibu hamil berminat dalam membaca buku KIA adalah kemauan, aktivitas, serta perasaan tertarik dan merasa senang. Kemauan ibu hamil untuk membaca buku KIA bisa ditimbulkan dari kesadaran bahwa buku KIA adalah buku yang penting untuk ibu hamil karena di dalamnya berisi materi penting untuk ibu hamil dalam menghadapi kehamilannya dan mencegah adanya komplikasi atau kelainan dalam kehamilannya. Oleh karena itu perlunya diadakan penyuluhan oleh tenaga kesehatan terkait dengan pentingnya buku KIA bagi ibu hamil.

Hampir seluruh ibu hamil bekerja sebagai ibu rumah tangga dimana sebagian besar aktivitas dilakukan di rumah. Hal ini membantu ibu hamil menyediakan waktu untuk membaca buku KIA. Ibu hamil bisa memanfaatkan waktu luang untuk membaca buku KIA. Aktivitas membaca buku KIA juga harus mendapatkan dorongan dari luar berupa dukungan dari keluarga. Ibu hamil yang mendapatkan dukungan dari keluarga akan merasa lebih termotivasi untuk membaca. Selain itu kemasan dari buku KIA harus cukup menarik perhatian dari ibu hamil. Perhatian ini bisa menimbulkan ketertarikan dan kemauan untuk membaca. Isi dari buku KIA juga harus jelas dan komunikatif, sehingga ibu hamil bisa dengan mudah memahaminya.

Menurut Soeatminah (1992), minat membaca pada orang yang tingkat pendidikan tinggi berbeda dengan orang yang lebih rendah tingkat pendidikannya. Perbedaan minat dikarenakan adanya perbedaan kemampuan dan kebutuhan. Hal ini jika dilihat dari pendidikannya, sebagian besar ibu hamil berpendidikan terakhir SMA. Pendidikan SMA dan perguruan tinggi merupakan level pendidikan yang relatif tinggi sehingga semakin tinggi pendidikan semakin tinggi pula minat membacanya. Orang dengan kesadaran yang tinggi untuk membaca akan mempunyai minat baca tinggi pula. Minat baca yang tinggi akan menyebabkan semakin banyaknya 
pengetahuan yang diperoleh begitu juga sebaliknya.

Hasil penelitian menunjukkan bahwa sebagian besar responden memiliki pengetahuan yang baik tentang buku KIA. Tabel silang antara pendidikan dengan pengetahuan ibu hamil tentang Buku KIA menunjukkan bahwa sebagian besar ibu hamil yang memiliki pengetahuan baik adalah berpendidikan terakhir SMA, dimana pendidikan SMA merupakan pendidikan yang tinggi. Pendidikan yang tinggi ini membuat ibu hamil lebih mudah dalam menyerap informasi yang diberikan. Beberapa informasi yang ada di dalam buku KIA

Serupa dengan penelitian yang dilakukan oleh Ramasamy (2013) yang berjudul "Hubungan Tingkat Pendidikan dengan Pengetahuan Tentang Antenatal Care dalam Kalangan Ibu Usia Subur", hasil penelitian menunjukkan bahwa terdapat hubungan di antara tingkat pendidikan dengan tingkat pengetahuan tentang antenatal care dalam kalangan ibu usia subur.

Pengetahuan adalah hasil tahu dari seseorang setelah melakukan pengindraan terhadap suatu objek tertentu. Nursalam (2003) menyebutkan bahwa faktor-faktor yang mempengaruhi tingkat pengetahuan diantaranya adalah pendidikan, usia, pekerjaan, informasi, pengalaman, lingkungan, sosial-ekonomi, dan sosial budaya. Pendidikan memiliki pengaruh yang besar karena seseorang dengan pendidikan yang tinggi akan memiliki pendalaman dan penalaran yang lebih mendalam. Seseorang dengan tingkat pendidikan tinggi maka akan semakin mudah dalam menerima informasi sehingga banyak pula pengetahuan yang dimilikinya.

Salah satu faktor yang mempengaruhi pengetahuan ibu hamil dalam penelitian adalah pendidikan. Tingkat pendidikan menentukan daya nalar seseorang dalam menyerap informasi. Pendidikan juga menentukan cara berpikir rasional seseorang dalam menghadapi permasalahan yang dihadapi. Pendidikan adalah arahan yang diberikan oleh seseorang kepada perkembangan orang lain untuk menuju cita-cita tertentu. Pengetahuan seseorang didasarkan pada pendidikan yang dimiliki, dimana pendidikan yang tinggi maka pengetahuannya juga akan baik, begitu pula sebaliknya.

Notoatmojo (2003) menjelaskan bawa pendidikan mempunyai peranan yang penting untuk menentukan kualitas dari manusia. Pendidikan diharapkan bisa memberikan pengetahuan kepada manusia untuk membangun keberadaan hidup yang lebih baik. Semakin tinggi pendidikan seseorang maka semakin mudah menerima informasi dan semakin banyak pengetahuan yang diperoleh begitu juga sebaliknya. Pendidikan yang kurang dapat menghambat perkembangan sikap seseorang terhadap nilai baru yang diperkenalkan sehingga pengetahuan yang diperoleh juga kurang.

Sebagian besar ibu hamil memiliki pendidikan terakhir SMA. Pendidikan SMA adalah pendidikan dengan tingkat yang sudah tinggi. Hal inilah yang menyebabkan semakin mudahnya ibu hamil dalam menerima dan menyerap informasi saat membaca buku KIA. Ibu hamil yang berpendidikan SMA dan diimbangi dengan minat membaca buku KIA yang tinggi, akan menimbulkan pengetahuan yang semakin baik pula. Seorang ibu hamil yang memiliki minat membaca tinggi akan berusaha untuk membaca dengan kemauan dan kesadarannya sendiri. Semakin sering ibu hamil membaca buku KIA, maka semakin banyak pengetahuan tentang buku KIA yang didapatkan.

Hasil uji statistik menggunakan uji korelasi Spearman Rank menunjukkan bahwa ada hubungan antara minat membaca buku KIA dengan pengetahuan ibu hamil tentang buku KIA. Semua kategori minat membaca dalam hal ini tinggi, sedang, dan rendah mempunyai kontribusi terhadap pengetahuan ibu hamil tentang buku KIA. Tabel silang antara minat membaca buku KIA dengan pengetahuan ibu hamil tentang Buku KIA menunjukkan bahwa ibu hamil dengan minat membaca kategori tinggi mempunyai kecenderungan pengetahuan yang baik.

Hampir sama dengan penelitian yang dilakukan oleh Nur Ma'arif (2010) tentang "Pengaruh Minat Baca Terhadap Prestasi Belajar Siswa di MA Abadiyah Gabus Pati 
Kelas XI", hasil penelitian menunjukkan bahwa pengaruh minat baca terhadap prestasi belajar siswa MA Abadiyah tergolong cukup. Minat baca siswa mempengaruhi dari prestasi belajar siswa MA Abadiyah. Hal ini serupa dengan hasil penelitian yang menunjukkan bahwa ibu hamil dengan minat yang tinggi mempunyai pengetahuan yang baik.

Ibu hamil yang mempunyai minat membaca buku KIA yang tinggi akan senantiasa berusaha mengisi waktu luangnya untuk membaca buku KIA. Ibu hamil merasa tertarik dan mulai perhatian dengan buku KIA. Ibu hamil memutuskan untuk mulai membacanya buku KIA dengan perasaan senang dan atas kemauannya sendiri.

Sebagian besar ibu hamil memiliki latar belakang pendidikan terakhir SMA dan perguruan tinggi. Pendidikan SMA dan perguruan tinggi adalah tingkatan yang tinggi dalam pendidikan di Indonesia Semakin tinggi pendidikan seseorang maka semakin tinggi minat membacanya. Farida Rahim (2008) berpendapat bahwa orang yang memiliki minat baca tinggi akan memiliki kesadaran yang tinggi untuk membaca sehingga semakin banyak pengetahuan yang didapatkan sedangkan orang dengan minat baca yang rendah akan memperoleh pengetahuan yang sedikit juga. Ibu hamil yang memiliki minat membaca tinggi untuk membaca buku KIA akan memiliki perasaan tertarik dan perhatian terhadap buku KIA dan timbul motivasi untuk membaca buku KIA. Ibu akan senantiasa meluangkan waktu untuk membaca buku KIA dan pengetahuan ibu hamil tentang materi yang ada pada buku KIA menjadi meningkat.

Mayoritas ibu hamil dalam penelitian ini bekerja sebagai ibu rumah tangga yang lebih banyak menghabiskan waktunya di rumah. Ibu hamil yang sudah memiliki minat baca yang cukup akan cenderung mempunyai intensitas membaca buku KIA yang lebih sering dibandingkan dengan ibu hamil yang bekerja di luar rumah. Ibu hamil yang memiliki minat membaca tinggi senantiasa mengisi waktu luang dengan membaca. Banyak hal-hal baru dan yang belum pernah diketahui akan ditemukan dengan membaca. Aktivitas membaca inilah yang secara otomatis akan menambah pengetahuan ibu hamil tentang bahan bacaan yaitu materi buku KIA yang sedang dibaca.

\section{KESIMPULAN}

Berdasarkan hasil penelitian dan pembahasan yang telah dilakukan tentang hubungan minat membaca buku KIA dengan pengetahuan ibu hamil tentang buku KIA di Polindes Pulungdowo-Tumpang Kabupaten Malang, dapat disimpulkan bahwa minat membaca buku KIA pada ibu hamil mempunyai hubungan dengan pengetahuan ibu hamil tentang buku KIA. Ibu hamil yang mempunyai minat membaca tinggi akan cenderung memiliki pengetahuan yang baik.

\section{SARAN}

Diharapkan Dinas Kesehatan melakukan penambahan media promosi kesehatan seperti poster terkait pentingnya buku KIA untuk ibu hamil, perlunya peningkatan dalam pemberian KIE tentang pentingnya buku KIA kepada ibu hamil sewaktu memeriksakan kehamilannya dan ibu hamil diharapkan tidak beranggapan bahwa buku KIA adalah buku yang hanya dibawa saat memeriksakan kehamilan, tetapi dianjurkan untuk membaca karena berisi informasi penting yang dapat mendeteksi dini adanya masalah dalam kehamilan.

\section{DAFTAR PUSTAKA}

Arikunto. 2006. Prosedur Penelitian Suatu Pendekatan Praktik. Jakarta: Rineka Cipta.

Azrul, A., Joedo, P. 2003. Metodologi Penelitian Kedokteran dan Kesehatan Masyarakat. Jakarta: Binurupa Aksara.

Depkes RI., JICA. 2003. Petunjuk Teknis Penggunaan Buku Kesehatan Ibu dan Anak. Jakarta.

Depkes RI. 2009. Buku Kesehatan Ibu dan Anak, Direktorat Jenderal Bina Kesehatan Masyarakat. Jakarta.

Hidayat. 2007. Metode Penelitian Keperawatan dan Tehnik Analisa Data. Jakarta: Salemba Medika.

Istiarti, T. 2000. Menanti Buah Hati. Yogyakarta: Media Persindo. 
Jamarah. 2005. Psikologi Belajar. Jakarta: Rineka Cipta.

Koentjoronongrat. 1997. Metode-metode Penelitian Masyarakat. Jakarta : PT Gramedia.

Notoadmojo, S. 2005. Ilmu Kesehatan Masyarakat. Jakarta: Rineka Cipta.

Notoadmojo, S. 2010. Metodologi Penelitian Kesehatan. Jakarta: Rineka Cipta.

Nur, M. 2010. Pengaruh Minat Baca Terhadap Prestasi Belajar Siswa di MA Abadiyah Gabus Pati Kelas XI. Under Graduates Thesis. Universitas Islam Negeri Sunan Ampel Surabaya. Tersedia di <http://digilib.uinsby.ac.id/8208/> [diakses tanggal 17 Januari 2017].

Nursalam. 2008. Konsep dan Penerapan Metodologi Penelitian Ilmu Keperawatan. Jakarta: Salemba Medika.

Prasetyo. 2005. Metode Penelitian Kuantitatif: Teori dan Aplikasi. Jakarta: PT. Rajagrafindo.

Rahim, F. 2008. Pengajaran Membaca di Sekolah Dasar. Jakarta: Bumi Aksara.

Ramasamy, A. 2013. Hubungan Tingkat Pendidikan dengan Pengetahuan Tentang Antenatal Care dalam Kalangan Ibu Usia
Subur. e-Jurnal Fakultas Kedokteran. Universitas Sumatera Utara. Tersedia di <http://jurnal.usu.ac.id/index.php/ ejurnalfk/article/view/1296/682> [diakses tanggal 17 Januari 2017].

Saifudin, A. 2012. Penyusunan Skala Psikologi. Yogyakarta: Pustaka Pelajar.

Sistiarani, C., Gamelia, E. 2012. Fungsi Pemanfaat Buku KIA terhadap Pengetahuan Kesehatan Ibu dan Anak pada Ibu. National Public Health Journal. Tersedia di <http://journal.fkm.ui.ac. $\mathrm{id} /$ kesmas/article/view/404> [diakses tanggal 22 Januari 2017].

Soeatminah. 1992. Perpustakaan, Kepustakawan dan Pustakawan. Yogyakarta: Kornisius.

Sugiyono. 2011. Statistika untuk Penelitian. Jakarta: Alfa Beta.

Suryabrata, S. 1998. Psikologi Pendidikan, Jakarta: Raja Grafindo Persada.

Survey Demografi dan Kesehatan Indonesia. 2012. Laporan Pendahuluan SDKI 2012. Tersedia di http://www.bkkbn.go.id/ [5 April 2013].

Sutarno. 2006. Manajemen Perpustakaan. Jakarta: Sagung Seto. 